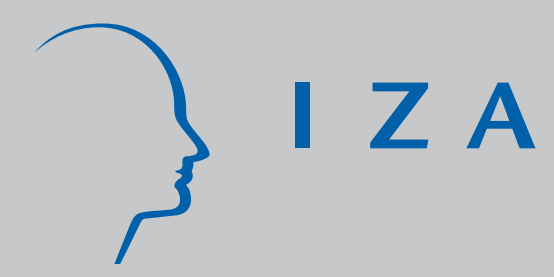

IZA DP No. 820

The Effects of Merit-Based Financial

Aid on Course Enrollment, Withdrawal and Completion in College

Christopher M. Cornwell

Kyung Hee Lee

David B. Mustard

July 2003 


\title{
The Effects of Merit-Based Financial Aid on Course Enrollment, Withdrawal and Completion in College
}

\author{
Christopher M. Cornwell \\ University of Georgia \\ Kyung Hee Lee \\ University of Georgia \\ David B. Mustard \\ University of Georgia and IZA Bonn
}

\author{
Discussion Paper No. 820 \\ July 2003
}

IZA

P.O. Box 7240

D-53072 Bonn

Germany

Tel.: +49-228-3894-0

Fax: +49-228-3894-210

Email: iza@iza.org

\begin{abstract}
This Discussion Paper is issued within the framework of IZA's research area Evaluation of Labor Market Policies and Projects. Any opinions expressed here are those of the author(s) and not those of the institute. Research disseminated by IZA may include views on policy, but the institute itself takes no institutional policy positions.
\end{abstract}

The Institute for the Study of Labor (IZA) in Bonn is a local and virtual international research center and a place of communication between science, politics and business. IZA is an independent, nonprofit limited liability company (Gesellschaft mit beschränkter Haftung) supported by Deutsche Post World Net. The center is associated with the University of Bonn and offers a stimulating research environment through its research networks, research support, and visitors and doctoral programs. IZA engages in (i) original and internationally competitive research in all fields of labor economics, (ii) development of policy concepts, and (iii) dissemination of research results and concepts to the interested public. The current research program deals with (1) mobility and flexibility of labor, (2) internationalization of labor markets, (3) welfare state and labor market, (4) labor markets in transition countries, (5) the future of labor, (6) evaluation of labor market policies and projects and (7) general labor economics.

IZA Discussion Papers often represent preliminary work and are circulated to encourage discussion. Citation of such a paper should account for its provisional character. A revised version may be available on the IZA website (www.iza.org) or directly from the author. 


\section{ABSTRACT}

\section{The Effects of Merit-Based Financial Aid on Course Enrollment, Withdrawal and Completion in College*}

Since Georgia unveiled its HOPE Scholarship in 1993, at least 15 other states have implemented or proposed merit-aid programs based on the HOPE model. A common justification for these actions is to promote and reward academic achievement, thereby inducing greater investments in human capital. However, grade-based eligibility and retention rules encourage other behavioral responses. Using data extracted from the longitudinal records of all undergraduates who enrolled at the University of Georgia (UGA) between 1989 and 1997, we estimate the effects of HOPE on course enrollment, withdrawal and completion, and the diversion of course taking from the academic year to the summer, treating non-residents as a control group. First, we find that HOPE decreases full-load enrollments and increases course withdrawals among resident freshmen. The combination of these responses results in a $12 \%$ lower probability of full-load completion and an annual average reduction in credits completed of about 0.8 or $2 \%$. The latter implies that between 1993 and 1997 Georgia resident freshmen completed almost 12,600 fewer credit hours than non-residents, or about 2,520 individual course enrollments. Second, the scholarship's influence on course-taking behavior is concentrated on students whose GPAs place them on or below the scholarship-retention margin. Third, program effect increased with the lifting of the income cap. Fourth, these freshmen credit-hour reductions represent a general slowdown in academic progress and not just intertemporal substitution. Finally, residents diverted an average of .5 credits from the regular academic year to the summer in each of their first two summers after matriculation, which amounts to a $22 \%$ rise in summer course taking.

JEL Classification: $\quad$ I2, J24

Keywords: $\quad$ human capital, merit-based aid, higher education

Corresponding author:

David B. Mustard

Department of Economics

Terry College of Business

University of Georgia

Athens, GA 30602

USA

Email: mustard@terry.uga.edu

\footnotetext{
* We thank Arthur Snow and workshop participants at Alabama, Cornell, Emory, Georgia State, Colorado-Denver, and the University of Georgia Institute of Higher Education for their helpful comments. An earlier version of this paper was also presented at the 2003 meetings of the American Economic Association. Cornwell and Mustard gratefully acknowledge the support of the NSF under grant SES-9986469, American Educational Research Association, and Terry College of Business through its Terry-Sanford Research Grant Program. Lee's research was funded in part by the American Education Finance Association.
} 


\section{Introduction}

Historically a large share of student aid for post-secondary institutions was need-based with the objective of increasing both access and choice. Merit-based aid constituted a relatively small fraction of total student financial aid, being largely confined to individual institutions' attempts to attract academically proficient students. However, since the early 1990s there has been a radical transformation in student financing as many state governments have committed millions of dollars to merit aid, in many cases dropping means tests entirely. The model for these state programs has been Georgia's HOPE ("Helping Outstanding Pupils Educationally") Scholarship. ${ }^{1}$

Initiated in 1993 and funded by a state lottery, the HOPE Scholarship covers tuition, fees and book expenses for all eligible high-school graduates attending Georgia public post-secondary institutions. Eligible students who attend in-state private institutions receive a fixed payment comparable to the value of the subsidy received by public-school enrollees. To qualify for the scholarship at one of Georgia's degree-granting public or private colleges, a high-school student must graduate with a "B" average. There are no income restrictions. $^{2}$ To retain HOPE a student must have 3.0 cumulative gradepoint average (GPA) at each check point. From September 1993 through April 2003, more than $\$ 1.9$ billion in scholarship funds have been disbursed to almost 800,000 students. $^{3}$

States have justified HOPE-style merit scholarships in three ways. One is to increase college enrollments in the state; another is to keep their best and brightest high-school graduates from attending college elsewhere. Cornwell, Mustard and Sridhar (2003) find that Georgia's program raised the overall

\footnotetext{
${ }^{1}$ Fifteen other states have implemented or proposed merit scholarships fashioned after HOPE. See Cornwell, Leidner and Mustard (2003) for a review of these programs.

${ }^{2}$ In the first year of the program, a household income cap of $\$ 66,000$ was imposed. This cap was raised to $\$ 100,000$ the following year and eliminated entirely thereafter.

${ }^{3}$ The most recent data on the number of HOPE recipients and the total value of their awards are available from the Georgia Student Finance Commission (www.gsfc.org).
} 
enrollment rate by $9 \%$ between 1993 and 1997, but "keeping the best and brightest in state" accounts for only about a third of the overall program effect. Further, they show that the enrollment increase attributable to HOPE amounts to only $10 \%$ of award recipients.

A third justification commonly offered for merit aid is the incentive it creates for academic achievement. At the same time, GPA requirements for eligibility and retention also encourage other behavioral responses like enrolling in fewer classes per term, withdrawing from classes when performing unsatisfactorily, and choosing less challenging courses. However, little attention has been devoted to these unintended consequences.

Our paper addresses this gap in the literature with the first empirical examination of the effects of HOPE's retention rules on academic choices in college. Using data extracted from the longitudinal records of all undergraduates who enrolled at the University of Georgia (UGA) between 1989 and 1997, we estimate the effects of HOPE on course enrollment, withdrawal and completion, and the diversion of course taking from the academic year to the summer. ${ }^{4}$ Our strategy treats non-residents, who are ineligible for HOPE, as a control group in a series of difference-in-differences (DD) regressions that contrast the behavior of in-state and out-of-state students before and after HOPE was implemented. Our main results can be summarized as follows.

First, we find that HOPE decreases full-load enrollments and increases course withdrawals among resident freshmen. The combination of these responses results in a $12 \%$ lower probability of full-load completion and an annual average reduction in credits completed of .8. The latter implies that between 1993 and 1997 Georgia resident freshmen completed almost 12,600 fewer credit hours than non-residents, or about 2,520 individual course enrollments. In addition, the scholarship's influence on course-taking behav-

\footnotetext{
${ }^{4}$ Of course, these decisions do not exhaust the possibilities for HOPE's influence. For example, the scholarship could affect a student's choice of major or elective courses. We are currently examining the evidence for both of these responses in a separate paper.
} 
ior is concentrated on students whose GPAs place them on or below the scholarship-retention margin and increased with the lifting of the income cap. Further, these freshmen credit-hour reductions represent a general slowdown in academic progress and not just intertemporal substitution. Finally, residents diverted an average of .5 credits from the regular academic year to the summer in each of their first two summers after matriculation.

The rest of the paper is organized as follows. Section 2 outlines the basic features of Georgia's HOPE program and how it should alter the academic choices of college students. Section 3 presents the details of our empirical strategy. Section 4 discusses our results and Section 5 concludes.

\section{Georgia's HOPE Scholarship: Rules and Incentives}

\subsection{Scholarship Rules and Awards}

To qualify for the scholarship, an entering freshman must have graduated from an eligible Georgia high school since 1993 with at least a "B" average and be a Georgia resident. ${ }^{5}$ For HOPE Scholars in degree-granting public institutions, the program covers tuition, HOPE-approved mandatory fees and a book allowance. The value of the award is about $\$ 3600$ for the 200203 academic year. HOPE Scholars in private, degree-granting institutions receive a fixed payment of $\$ 3000$ per academic year toward tuition. ${ }^{6}$

\footnotetext{
${ }^{5}$ To reduce the number of HOPE Scholars in an attempt to avoid future funding shortages, the eligibility rules were tightened for students who graduated high school in 2000 to demand a "B" average in "core-curriculum" subjects. Interestingly, the predicted $35 \%$ drop in HOPE qualifiers did not materialize. The number of HOPE recipients declined only $4.3 \%$ from the previous year, raising the question of whether grades were inflated in reaction to the stiffer requirements ("Hope Suffers Funding Shortage," Athens Banner Herald, 30 Sep 2000).

${ }^{6}$ Its value was initially set at $\$ 500$ in 1993 and rose to $\$ 1000$ in 1994 and $\$ 1500$ in 1995, but the private-school award was not tied to merit during these years. These awards supplemented a $\$ 1000$ Tuition Equalization Grant (TEG) Georgia provided students attending in-state private schools. Beginning in 1996, the HOPE payment to students at-
} 
To retain HOPE in college, scholarship recipients must maintain a 3.0 GPA. Each student's GPA is checked at three intervals, corresponding to points where she has earned enough credits to be a sophomore, junior, and senior. During our sample, UGA operated on the quarter system, so these check points occurred at 45, 90, and 135 credit hours. ${ }^{7}$ Fifteen credit hours is considered a full load for one term; therefore, 45 credit hours constitutes a full load over the academic year. If a student's cumulative GPA is at least 3.0 at a given checkpoint, the scholarship is awarded until the next checkpoint. If a student's cumulative GPA falls below 3.0 at a checkpoint, she loses her award, but can regain it at the next checkpoint if she raises her GPA to the 3.0 threshold. Those who do not qualify for HOPE based on their high-school GPA can become eligible after 45 credit hours if their GPA is at least 3.0.

\section{$2.2 \quad$ Incentives of Retention Rules}

Figure 1 plots kernel density estimates of cumulative GPA distributions of typical resident and non-resident first-year students at UGA between 1992 and 1995 (the year before HOPE's inception to the year the income cap was eliminated). ${ }^{8}$ By "typical" we mean those who matriculate at UGA in the fall term of the same year they graduate from high school. Prior to HOPE, the grade distribution for non-residents lies to the right of the resident distribution and exhibits less variance. After HOPE, and especially after the income cap was removed in 1994 and 1995, the situation reverses,

tending in-state private schools was increased to $\$ 3000$ and the merit rules for eligibility were imposed. See Sridhar (2001).

${ }^{7}$ Until 1997, the year our sample ends, the University system was on quarters. In 1998 it switched to semesters and students are now evaluated at 30,60, and 90 semester hours.

${ }^{8}$ Cumulative GPA is the average of earned grade points accumulated since a student matriculated at UGA:

$$
\text { Cumulative GPA } \text { GP }^{m}=\frac{\sum_{i=1}^{m} \sum_{j=1}^{n}\left(\text { Grade point }_{j}^{i} \times \operatorname{Credit}_{\operatorname{hours}_{j}^{i}}\right)}{\sum_{i=1}^{m} \sum_{j=1}^{n} \operatorname{Credit}_{\operatorname{hours}}^{i}}
$$

where $i$ and $j$ index the academic term and GPA-relevant courses (i.e., courses whose grades are included in GPA computation), respectively. 
with the resident distribution exhibiting a conspicuous peak at 3.0. More specifically, much of the mass of the resident distribution between 2.5 and 2.9 in 1992 moved to the 3.0-3.2 interval by 1995. These shifts suggest that the HOPE retention rules have led first-year residents to earn higher grades. Of course, tying retention to having a 3.0 GPA at regular credithour intervals encourages a variety of grade-enhancing strategies. Some of these are intended and may lead to greater investments in human capital, while others are unintended and probably do not increase human capital.

As intended, some students increase their effort. Others respond by substituting market work for school work due to the income effect associated with HOPE. To the extent that students attend classes more regularly and complete their assignments more assiduously, human capital investments will rise. Trading work hours for study hours may also increase human capital since typical college-student jobs require few skills and involve little training.

Among the possible unintended consequences, we concentrate on three program responses involving relatively low-cost adjustments in course loads and difficulty. One is to enroll in fewer courses at the beginning of the term. A one-course reduction from a full load during the first year guarantees an extra term of funding by forestalling the HOPE checkpoint no matter how low a student's GPA is. In addition, a lighter load can translate into higher per-class effort and the likelihood of earning a higher grade on each class without raising overall effort. Finally, because HOPE benefits do not expire, any propensity to take lighter loads is exacerbated.

Another is for a student to withdraw from classes in which she is performing poorly. Because withdrawn classes do not enter the GPA, students who are near the HOPE margin and are not doing well in a class have an added benefit from withdrawing. The combined effects of enrolling in lighter loads and withdrawing more frequently will show up in reduced credits completed.

A third unintended response to the retention rules is to take easier classes. 
Such a choice could be made on the basis of course content, a professor's reputation for grading leniently, or timing. An example of the latter is deferring courses to the summer, when grade distributions are significantly more generous and course content is often truncated.

While our empirics focus on these unintended behavioral responses, there is an additional factor, unrelated to the retention rules, that must be considered. The issue is whether, relative to out-of-state students, HOPE has led to the selection higher quality residents in the admissions process. The grade distribution shifts in Figure 1 could be due to an improvement in resident SAT scores, high-school GPAs (HSGPAs) and advanced course taking in high school, relative to non-residents after HOPE. We check for this by estimating DD regressions of SAT scores, HSGPAs and AP courses taken. As we will show, there is little evidence that HOPE increased relative quality (as measured by these high-school performance variables) of in-state enrollees.

Finally, we acknowledge that even these unintended responses could enhance human-capital acquisition. For example, taking fewer courses as a first-year student could aid in the transition to college and better facilitate learning throughout one's college career. However, the option to take fewer (and easier) courses has always existed and did not arise with the HOPE Scholarship. Further, at an institution like UGA where most students come from middle- and upper-income households (65\% of freshmen were ineligible for HOPE in 1993, when there was an income cap of $\$ 66,000$ ), the scholarship matters little for college attendance (even attendance at UGA). Thus, a reasonable conjecture might be that the scholarship incentives should be trumped by other factors such as the labor-market returns to academic choices.

However, the fractions of typical resident and non-resident first-time freshmen (FTF) that enrolled in a full-course load, withdrew from a class and completed a full load suggest otherwise. These data, covering the 1989-97 
period, are plotted in Figures 2, 3, and $4 .^{9}$ The percentage of resident freshmen enrolling in full-course loads fell from $82 \%$ to $70 \%$ after 1993 , while the percentage of non-resident full-load enrollees remained at $80 \%$ or above. Similarly, the fractions of residents and non-residents withdrawing from a class diverged sharply with the introduction of the scholarship. The combined effect of residents' drop in full-load enrollments and rise in course withdrawals was a precipitous decline in the full-load completion rate from $67.6 \%$ to $44.2 \%$. In contrast, the percentage of non-residents completing full loads fluctuated fairly narrowly around 60 during the entire period.

\section{Empirical Strategy}

\subsection{Model}

As described in Section 2, the HOPE Scholarship may influence students' course-taking behavior in a number of ways. Our empirics deal with four: enrolled courses, courses withdrawn, courses taken, and summer-school enrollments. We examine both qualitative (e.g., whether a student enrolls in a full load) and quantitative (e.g., number of credit hours enrolled) responses.

To estimate the scholarship's effect on these academic outcomes, we contrast the responses of residents before and after the HOPE "treatment" with those of non-residents who serve as a control group. This strategy leads to DD regressions of the form

$$
y_{i t}=\alpha+\beta G A_{i} \cdot H_{t}+X_{i, 1}^{\prime} \gamma+X_{i, 2}^{\prime} \delta+\epsilon_{i t},
$$

where $y_{i t}$ is an outcome measure (either discrete or continuous) for a typical first-year student $i\left(i=1, \ldots, N_{t}\right)$ in academic year $t(t=89,90, \ldots, 97)$;

\footnotetext{
${ }^{9}$ First-time freshmen are students who have not enrolled in another postsecondary institution before entering UGA.
} 
$H_{t}$ is a HOPE indicator that equals 1 for students who matriculated in 1993

or later; $G A_{i}$ is Georgia resident dummy; $X_{i, 1}$ includes race, gender and class-year dummies (e.g., the indicator for the 1989 class year equals 1 for students who matriculated in 1989); $X_{i, 2}$ contains pre-college characteristics such as HSGPA, SAT scores and AP credit hours; and $\epsilon_{i t}$ is the error term. The program effect is captured by $\beta$, the coefficient on the interaction term between the Georgia residency and HOPE dummies.

For each outcome we estimate two basic specifications - a simpler model that omits the controls in $X_{i, 2}$ and a more complete specification that includes these high-school performance variables. Because the influence of the retention rules should be greater for students on or below the retention margin than those with high GPAs whose risk of loss is low, we also estimate the effects of the scholarship at different intervals of the grade distribution. Further, we extend the model in (1) to allow the estimated HOPE effects to vary over time. We do this for three reasons. First, as a check on our empirical strategy, we want to determine whether our reported effects are coincident with HOPE's introduction. Second, we would like to assess the importance of the income cap in our empirics. Due to the income restriction on eligibility in 1993 and 1994, we have assigned students to the treatment group who do not receive the scholarship, thus likely underestimating the impact of HOPE. Third, we expect gaming the system to be more pervasive as information about the retention rules becomes more widely diffused.

\subsection{Data}

Our empirical strategy is implemented with data compiled on all undergraduates enrolled at UGA between 1989 and 1997. The Office of Student Financial Aid provided information on each student's HOPE status, the dol-

lar amount of each HOPE award, the reason for HOPE ineligibility (if any), the number of HOPE attempted hours and GPA for HOPE scholars by term. 
Incomplete and withdrawn credit hours are included in HOPE attempted hours, but not in UGA attempted hours. We distinguish the term "HOPE Scholar" from "HOPE recipient" throughout this paper. The former designates a student who received the scholarship for at least one year in her UGA career. The latter refers to a HOPE Scholar receiving the award in a specific term or year.

From the Registrar's Office, we obtained credit hours enrolled, attempted and earned, cumulative GPA, matriculation and graduation terms (if available), course selection, major field of study, and AP credits. HOPE cumulative GPA is calculated to determine HOPE eligibility and differs from the UGA cumulative GPA. The latter depends only on earned grade points since matriculation at the university. Also, withdrawn credit hours are counted in HOPE attempted hours, but neither UGA attempted nor earned hours.

Finally, the Undergraduate Admissions Office provided data on various pre-college and personal characteristics such as HSGPA, SAT scores, high school attended, residency, ethnicity, gender, and age. ${ }^{10}$ We obtained two versions of HSGPA, one from the Registrar's Office which was unweighted, and the other from the Admissions Office which was weighted according to the scheme designed for UGA admission rules and standards. ${ }^{11}$ Because the grading scale is not equivalent across high schools and the quality of curriculum or the level of the courses taken (e.g., standard, college preparatory, honors, and AP classes) is not the same for all students, we use the weighted HSGPA provided by the Admissions Office.

Over the sample period, about 38,200 enrollees are included in the dataset. However, because we want to examine how HOPE affects academic choices

\footnotetext{
${ }^{10}$ The College Board recentered SAT scores for tests taken on or after 1 April 1995 to reestablish the average SAT I verbal and math scores near the midpoint of the 200-to-800 scale. SAT scores from the Admissions Office for students in 1989 through 1994 classes were on the original scale. We recentered pre-April 1995 SAT scores using the College Board's SAT I individual score conversion table.

${ }^{11}$ Weighted GPA = raw GPA + weight, where the weight assigned to each applicant ranged from -0.1 to 0.7 . The average weighted GPA was 3.29 over the sample period.
} 
throughout students' college careers, we exclude transfer students and limit the sample to those who enrolled at UGA as FTF. Further, we restrict attention to those FTF we regard as "typical" (those who matriculated at UGA in the fall term of the same year as they graduate from high school). Thus we exclude students who matriculated at UGA before graduating from high school, during the summer term after they graduated from high school, and after the fall term following their high-school graduation, but who were never enrolled in any other post-secondary institution. Typical FTF number roughly 31,000 and comprise nearly 95\% of all FTF from 1989-97.

Table 1 provides a breakdown of typical FTF in our sample by residency and scholarship status for each class year. After dropping to 3,042 in 1991, the number of typical FTF rose steadily to 4,165 in 1997. In HOPE's first year, when the $\$ 66,000$ income cap was in force, only $35.2 \%$ (949) of typical FTF Georgia residents entered with the scholarship. In 1994, the income cap was increased to $\$ 100,000$ and this percentage increased to 75.5. After the income cap was removed in 1995, almost all resident typical FTF started their careers at UGA as HOPE Scholars.

Table 2 reports the means and standard deviations of all of the variables in the sample, separately for residents and non-residents, over the pre- and post-HOPE periods. The resident-non-resident contrasts in the first three rows of the table are consistent with those displayed in Figures 2, 3, and 4 and serve as a preview of our empirical results.

\section{Results}

\subsection{HOPE's Effects on Selection}

Because the grade distribution changes in Figure 1 may be explained by an increase in the relative quality of Georgia-resident enrollees, we begin by examining HOPE's effect on selection. To test this proposition, we estimated 
DD regressions for SAT scores, HSGPAs and AP courses taken, the results of which are given in Table 3. The estimated HOPE effect of 4.479 for SAT verbal score is the only one that is statistically significant at the 0.1 level. The program effects for the other high-school achievement variables (SAT math and total scores, HSGPAs and AP credits) are all small and statistically insignificant. Thus, it appears that HOPE has not led to the relative improvement in the quality of resident enrollees. Consequently, we can not ascribe the grade distribution shifts in Figure 1 to HOPE's influence on the admission process.

\subsection{Full-Course Loads}

We now consider HOPE's impact on the probability a student enrolled in a full load, withdrew from a class, and completed a full load of courses. The program effect on completion will reflect adjustments in both course enrollment and withdrawal. These results are provided in Table 4, with columns 1, 3 and 5 presenting the base specification, and the even-numbered columns adding the high-school performance control variables (HSGPA, math and verbal SAT scores, and the number of AP credits). ${ }^{12}$

Column 1 reports an estimated HOPE effect on the probability of enrolling in a full-course load of -0.045 , which is statistically significant at the 0.01 level. This estimate implies resident freshmen were 4.5 percentage points less likely to enroll in a full load because of HOPE. When high-school performance characteristics are included in the regression (column 2), the estimated HOPE effect changes only slightly, rising in magnitude to 4.7 percentage points. Since the percentage of typical first-year residents enrolling in a full load in the pre-HOPE years is 82.2 , these results mean a 5.5 to $5.7 \%$ drop in the full-course-load enrollment rate.

\footnotetext{
${ }^{12}$ Compared to baseline regressions, we lose 412 students when we estimate the full specification, because of missing values in high-school performance controls.
} 
Students can respond to the HOPE incentive to reduce course loads both by signing up for fewer credits and withdrawing from courses in which they are not performing well. Course withdrawal may be an especially important strategy for a student on the margin of HOPE retention, because withdrawing will not affect her GPA. The program effect estimated in column 3 indicates that the scholarship increased the likelihood of Georgia resident withdrawals by 4.8 percentage points. This translates into a $18.4 \%$ increase in the withdrawal rate, given that the pre-HOPE mean for resident enrollees is 26.1. As in the full-load enrollment case, this finding is robust to the inclusion of high-school achievement variables.

HOPE's influence on course enrollments and withdrawals is ultimately realized in credits taken (completed). The last two columns of Table 4 give the estimated HOPE effects on the probability of taking a full load. The base specification suggests that the scholarship caused the likelihood of taking a full load to drop by 7.6 percentage points. Adding the high-school achievement variables leaves this result virtually unchanged. Since the pre-HOPE percentage of typical first-year residents taking a full load is 64.2, this implies a $11.8 \%$ decline in the full-course-load completion rate.

Before we turn to the intensive margin, it is worth noting some of the other findings in Table 4. Holding high-school achievement constant, women are more likely to complete a full-course load by 3.2 percentage points, and are both more likely to sign up for a full load and less likely to withdraw from a class. Blacks are 4.3 percentage points more likely to complete a full load of courses, but are no less likely to withdraw. Not surprisingly, the probability of taking a full load increases with high-school achievement, with HSGPA having the greatest impact. Qualitatively, these findings are repeated in the credit-hours regressions. 


\subsection{Credit Hours}

On average, how many fewer credit hours are completed by freshmen because of HOPE, and to what extent is the decrease due to enrolling in a lighter load versus course withdrawal? Table 5 reports DD regression results for the number of credit hours enrolled (columns 1 and 2), withdrawn (columns 3 and 4), and taken (columns 5 and 6). Again, columns 1, 3, and 5 give the base specification and columns 2, 4, and 6 add the high-school performance variables.

The baseline estimated program effect on credit hours enrolled is -0.426 (with a $p$-value of 0.06 ), which implies that HOPE reduced the average Georgia-resident course load by about 0.43 credits. As in Table 4, including the high-school achievement control has little impact; the coefficient estimate falls to -.402 (and the $p$-value rises slightly). ${ }^{13}$ Since the pre-HOPE mean credit hours of typical first-year residents is 44.22 , this result translates into about a $1 \%$ decrease in enrolled hours.

Columns 3 and 4 show the estimated program effects on withdrawn hours are virtually equivalent to those for hours enrolled, but with somewhat smaller standard errors. Thus, the impact of the scholarship on completed hours is roughly $0.8-0.85$ credits. This is shown explicitly in columns 5 and 6. A 0.85 credit per year program effect means that between 1993 and 1997 Georgia residents completed almost 12,600 fewer credit hours than non-residents, or about 2,520 individual course enrollments.

Consistent with the extensive-margin findings in Table 4, holding highschool performance constant, women withdraw 0.2 less credit hours and blacks enroll in and complete about 1.5 more hours. Further, the number of credit hours taken rises with HSGPA, SAT math scores, and AP credits,

\footnotetext{
${ }^{13}$ Although its eligibility and retention rules rules are somewhat different, Binder and Ganderton (2002), in their study of New Mexico's merit-based SUCCESS Scholarship, report that program also led college students to reduce the number of registered and completed credit hours during their first two semesters.
} 
while it decreases with SAT verbal scores.

\subsection{HOPE Effects Throughout the GPA Distribution}

The program effects reported in Tables 4 and 5 should be driven by students on or below the margin for HOPE retention. Students far above the 3.0 GPA retention standard should be the least likely to game the system, because they have the lowest risk of scholarship loss. To test this, we repeat the analyses depicted in Tables 4 and 5 by cumulative GPA category. ${ }^{14}$

Tables 6 and 7 present the results of this exercise. We estimated the full specification given in (1) for four separate cumulative GPA categories: $<2.7,2.7-3.3,3.3-3.5$ and $>3.5$. Of 30,705 typical first-year students (whose records contain high-school performance controls), there were 238 students with no cumulative GPA, 13,675 with cumulative GPAs below 2.7, 9,790 between 2.7 and 3.3, 2,805 between 3.3 and 3.5, and 4,197 above 3.5.

First, consider the scholarship's influence on the extensive margin in Table 6. Panel A shows that residents at or below the retention margin are less likely to enroll in a full load of courses because of HOPE. For those with GPAs between 2.7 and 3.3 , the effect is 5.1 percentage points; 8.7 percentage points for students with GPAs below 2.7. Both estimates are statistically significant at the 0.01 level. In contrast, the coefficient estimates for students in the two highest GPA categories are essentially zero. Panel B presents the withdrawal results, which display a somewhat different pattern. As predicted, the estimated program effect is large and statistically significant for students with GPAs under 2.7 and insignificant for those with GPAs between 3.3 and 3.5 and above 3.5. In this case, however, the HOPE effect is also statistically insignificant for those whose GPAs are at the retention margin (between 2.7 and 3.3). The results for full-load completion, given in panel $\mathrm{C}$, follow the

\footnotetext{
${ }^{14}$ We also estimated the program effects by HSGPA and SAT score categories, and the same basic pattern emerges. We focus on the effects using the cumulative college GPA because it is the measure that counts in award determination.
} 
pattern of the course-enrollment estimates, declining in magnitude as the GPA increases. Students with GPAs less than 3.3 are at least 9 percentage points less likely to complete a full load. For students with GPAs greater than 3.3 the estimated HOPE effect is statistically insignificant; those in the highest GPA category are entirely unaffected by the scholarship.

The estimated program effects on credit hours, reported in Table 7, are consistent with the extensive margin findings. In general, HOPE's influence weakens as GPA rises and the statistically significant program responses are concentrated in the $<2.7$ category. Overall, the results suggest that HOPE led to a 1.6 credit-hours reduction for students with the lowest GPAs and a little more than a half credit drop among students in near the retention margin (although the latter result is not as strong).

To summarize, disaggregating our analysis by GPA confirms that HOPE's influence on course-taking behavior is, as one would predict, concentrated on students who are on the retention margin or whose GPA falls below the 3.0 cutoff. Further, as expected, it shows that high-achieving students who are least likely to lose their merit awards are generally unaffected by the retention rules.

\subsection{HOPE Effects Over Time}

Next we examine the temporal pattern of the scholarship's influence on course-taking behavior. This is important for three reasons. First, as a check on our empirical strategy, we want to determine whether our reported effects are coincide with HOPE's introduction. Second, we would like to assess the importance of the income cap in our findings. The income restriction on eligibility in 1993 and 1994 places some students in the treatment group who do not receive the scholarship, which likely causes the impact of HOPE to be underestimated. Third, as information about the retention rules becomes more widely diffused, we expect gaming the system to be more pervasive. 
Tables 8 and 9 present the results of our DD regressions where the HOPE effect varies by year. The year HOPE was introduced (1993) is the reference period. Again, consider first the extensive margin estimates, which are given in Table 8. Consistent with the date of HOPE's introduction, the estimated pre-1993 effects are, with just one exception, uniformly small (or of the "wrong" sign) and statistically insignificant for each outcome. In contrast, after 1994 when the income cap was lifted, the coefficient estimates are larger in magnitude (and all with the "correct" sign) and much more precisely estimated. Second, in each case the post-HOPE coefficient estimates increase in magnitude over the period. After the income cap is removed in 1995, the estimated HOPE effects for course enrollment doubled, while the withdrawal and full-load completion effects rose by 50\%. By 1997, the scholarship had reduced the probability that a freshman would take a full load by almost 12 percentage points (relative to 1993). Clearly, as the income cap was eliminated and larger fractions of students became eligible, the extent of HOPE's influence on these extensive margins grew.

On the intensive margin, captured in Table 9, we see generally the same pattern, most clearly in the case of course withdrawals. Again, with just one exception, all pre-HOPE coefficient estimates are statistically insignificant. At the end of the sample period, residents were completing, on average, 1.3 fewer credit hours (compared with 1993 levels). Interestingly, however, the program effect on course enrollments is precisely estimated only in 1995 and falls in magnitude and precision thereafter, so that course withdrawal becomes the dominant behavioral response.

\subsection{Delay or Intertemporal Substitution}

First-year students respond to the HOPE retention rules by enrolling in fewer courses, withdrawing more frequently, and reducing the total number of credits they take. While these findings are interesting, it is also important to 
understand how the retention standards are affecting students' course-taking behavior after their first year in college. Do the decisions that residents make to take fewer credits in their first year leave them behind their nonresident counterparts for the remainder of their undergraduate careers? Or do residents intertemporally substitute their course load by taking fewer credits in their early years and more hours in their later years?

We address this question by first estimating HOPE's effect on the probability of taking a full load and credits completed in each school-year. ${ }^{15}$ The findings are reported in Table 10. Except for the first year $(-0.074)$, the estimated HOPE effects for the extensive margin are all very close to zero and statistically insignificant: 0.004 for the second, 0.006 for the third and -0.011 for the fourth year. Correspondingly, none of the intensive margin effects are statistically significant after the first year. Thus, the retention rules do not simply induce intertemporal substitution, but on balance, slow the typical resident's progression through college.

However, the results presented in Table 10 may be problematic for two reasons. First, the income cap weakens the experiment for the 1993 and 1994 classes. Second, the prospects for intertemporal substitution are somewhat obscured because the analysis unevenly lumps together several pre- and postHOPE cohorts. Therefore, we repeated this analysis with only 1990 and 1995 classes, the latter being the first "full-HOPE-coverage" cohort and the former being the most recent never to benefit from the scholarship. The estimates from these regressions are given in Table $11 .^{16}$ Two findings are evident in this more refined experiment: (a) the first-year program effect estimates are

\footnotetext{
${ }^{15}$ In our sample, there are 31,117 typical students in the first year, 23,923 in the second year, 18,981 in the third year, and 14,755 in the fourth year. We lose students as we move from earlier to later years, not because they drop out, but because we can not follow 199597 class-year students through their fourth, third and second years, respectively. Given that only $36 \%$ of 1993 typical FTF graduated in four years and $53 \%$ in five years, and $44 \%$ of 1994 typical FTF graduated in four years, it was also impossible to follow students through to their graduation.

${ }^{16}$ Unfortunately, we cannot follow the 1995 class into its fourth year.
} 
larger, and (b) the contrast between the first and later years grows. In this case, HOPE lowers the probability that first-year residents complete a full load by 8.7 percentage points and decreases the number of credits they take by about 1.7. The second and third-year program effect estimates are much smaller and all are statistically insignificant. The comparison between these two classes is strong evidence that the scholarship has generally slowed down academic progress.

\section{7 $\quad$ Summer-School Course Taking}

As noted in Section 2, HOPE retention rules could induce students to take easier classes, where difficulty may be gauged by content, instructor's reputation, or timing. Because it is easily observed, we focus on timing - specifically HOPE's influence on the probability of taking courses in summer school and the number of credit hours completed during the summer. Summer-school courses are generally more leniently graded and often cover less material. At UGA, for example, the mean GPA for typical FTF was 2.81 during the summer of 1993, compared with 2.66 in the fall of 1992, and this fall-summer GPA gap widens during the HOPE period.

The estimated HOPE effects on summer-school course taking are presented in Table 12. First, consider the qualitative findings in Panel A. Residents are 3.5 percentage points more likely to take courses in their first summer (i.e., the summer immediately following the first academic year) due to HOPE. The program effect estimates are also positive in the subsequent summers, but statistically insignificant. However, the evidence on the intensive margin is stronger. Panel B shows that residents take almost 0.5 more summer credits in their first and second summers. Since the pre-HOPE mean of resident summer credit hours is 2.28 , this implies summer-school credits completed by residents per year rose $22 \%$ because of the scholarship. Together, panels $\mathrm{A}$ and $\mathrm{B}$ imply that HOPE has induced students to divert 
course taking to the summer to meet HOPE retention requirements.

\subsection{Discussion}

The findings concerning the effects of HOPE's GPA-based retention rules motivate us to discuss some of the broader implications of HOPE-style merit aid. First, one of the primary objectives of merit aid is to promote effort, but the incentives for students to work harder are fairly narrowly tailored. Students who are slightly above or below the grade-point requirement will have stronger incentives to work harder, but incentives to put forth more effort are fairly modest for low and high achievers who are unlikely to gain or lose HOPE.

Second, grade-based retention rules create incentives that partially undermine the objectives to reward students for increased effort. Students can adjust their GPAs in numerous ways other than increasing their effort, such as enrolling in fewer credit hours, withdrawing from more classes, and taking fewer hours. Because effort is costly, students may seek other ways to maintain their GPAs than working harder.

Third, a grade-based merit-aid program will reward low-achieving students who take less than a full load. A student who initially qualifies for an award, but who cannot retain it in college, can extend her scholarship for an extra term by taking less than a full load and deferring the date when she is evaluated for retention.

Fourth, UGA has become increasingly concerned about the institutional costs of students enrolling in fewer classes. While colleges encourage students to complete degrees in four years, the scholarship's incentives to take fewer classes may work against that goal. Also, although UGA has enrolled more students during the HOPE period, the number of credit hours generated has been relatively flat. This is a concern for state institutions whose funding is largely based on the number of student credit hours generated. For example, 
given that an average of about 3,150 typical Georgia residents entered UGA in each post-HOPE year (1993-97), the HOPE effect of -0.8 means that residents completed almost 2,520 fewer credit hours per year than non-residents, resulting in a lower level of state funding than would have otherwise obtained.

Finally, although HOPE-style aid may enhance human capital investment by encouraging some students to work harder, it induces others to take fewer and easier courses, especially early in their college careers. Our findings clearly indicate that the latter are the empirically more important behavioral responses. While it is difficult to determine the optimal pattern of class taking within and across class years for maximizing the value of the human capital investment, the option to take fewer and easier courses existed prior to HOPE. Further, as we pointed out in Section 2, it is somewhat surprising that HOPE influences behavior at all, given the over-riding importance of the labor market and that HOPE is infra-marginal for virtually all UGA students in their decisions whether to attend college. A likely explanation of the scholarship's influence is that the student responses we observe emerge from intra-household bargaining over HOPE rents in the decision where to attend college. It is not uncommon for UGA undergraduates to admit to being "bribed" to forgo an out-of-state or private-school alternative with an offer of a car. Using county-level data on car registrations and HOPE incidence in Georgia over the 199396 period, Cornwell and Mustard (2002) examine the relationship between car registrations and the number of HOPE recipients. They report an estimated the elasticity of registrations with respect the number of recipients attending students attending public, 2- and 4-year colleges of .02. The implication is that doubling a county's scholarship winners (attending a public college) will increase the number of registered cars in the county by $2 \%$. 


\section{Conclusion}

The recent and striking transformation from need- to merit-based aid in the last decade has been justified in part by its incentives to encourage students to work harder and thereby invest more in human capital. However, because students can increase their GPAs through a variety of mechanisms, grade-based, merit-aid programs produce some unintended consequences. Using a unique dataset constructed from the longitudinal records of all undergraduates who enrolled at the University of Georgia between 1989 and 1997, we estimated difference-in-differences (DD) regressions of the effects of HOPE on course enrollment, withdrawal and completion, and the shifting of course credits to the summer, treating non-residents as a control group. Our main findings are listed below.

First, controlling for a detailed set of student characteristics that includes high-school GPA, SAT scores, advanced placement credits, race and gender, freshmen residents were almost $6 \%$ less likely to enroll in a full-course load and over $18 \%$ more likely to withdraw from a class because of HOPE. The combination of these responses decreased the probability that a resident freshman would complete a full load by about $12 \%$.

Second, on the intensive margin, HOPE reduced the average completed credits by 0.8, which implies that between 1993 and 1997 Georgia resident freshmen completed almost 12,600 fewer credit hours than non-residents, or about 2,520 individual course enrollments. Further, these effects can be attributed roughly equally to HOPE's influence course enrollments and withdrawals.

Third, estimating these program effects by cumulative GPA categories confirmed that HOPE's influence on course-taking behavior is concentrated on students who are on the scholarship-retention margin or whose GPA falls below the 3.0 cutoff. Fourth, allowing the HOPE effects to vary by year 
revealed a rise in magnitude as the income cap was lifted and more students became eligible for the award. Another implication of this exercise is that the overall program effects are likely under-estimated, because students were assigned to the treatment group in 1993 and 1994 who did not receive the scholarship.

Fifth, the evidence suggests that these freshmen credit-hour reductions represent a slowdown in academic progress and not just intertemporal substitution. Credit-hour DD regressions involving the 1990 and 1995 entering classes in their first, second and third years indicated a statistically significant program effect of -1.7 credit hours in the first year, followed by much smaller and statistically insignificant credit-hour increases in the following years.

Finally, we examined HOPE's incentive to take less challenging courses by estimating the program's effect on the probability of taking summer-school classes and the number of credit hours taken in summer school. Residents were more likely to take courses in the summer following their first academic year, but there was very little difference between residents and non-residents in the subsequent summers. However, the estimated effects were more striking in terms of credit hours; the data suggest that during the first two summers after their first academic year residents summer-school course-taking rose $22 \%$ because of HOPE. 


\section{References}

Binder, Melissa and Philip T. Ganderton. 2002. "Musical Chairs In Higher Education: Incentive Effects Of A Merit-Based State Scholarship Program," University of New Mexico Department of Economics Working Paper.

Cornwell, Christopher M. and David B. Mustard. 2002. "Merit-Based College Scholarships and Car Sales." University of Georgia Department of Economics Working Paper.

Cornwell, Christopher M., Mark Leidner and David B. Mustard. 2003. "Rules, Incentives and Policy Implications of Large-Scale Merit-Based Financial Aid Programs." University of Georgia Department of Economics Working Paper.

Cornwell, Christopher M., David B. Mustard and Deepa J. Sridhar. 2003. "The Enrollment Effects of Merit-based Financial Aid: Evidence from Georgia's HOPE Scholarship." University of Georgia Department of Economics Working Paper.

Sridhar, Deepa J. 2001. Postsecondary Enrollment Effects of Merit-Based Financial Aid: Evidence from Georgia's HOPE Scholarship Program. PhD Dissertation, Department of Economics, The University of Georgia, Athens GA. 
Figure 1 Cumulative GPA Distributions of Typical FTF, Residents vs Non-residents

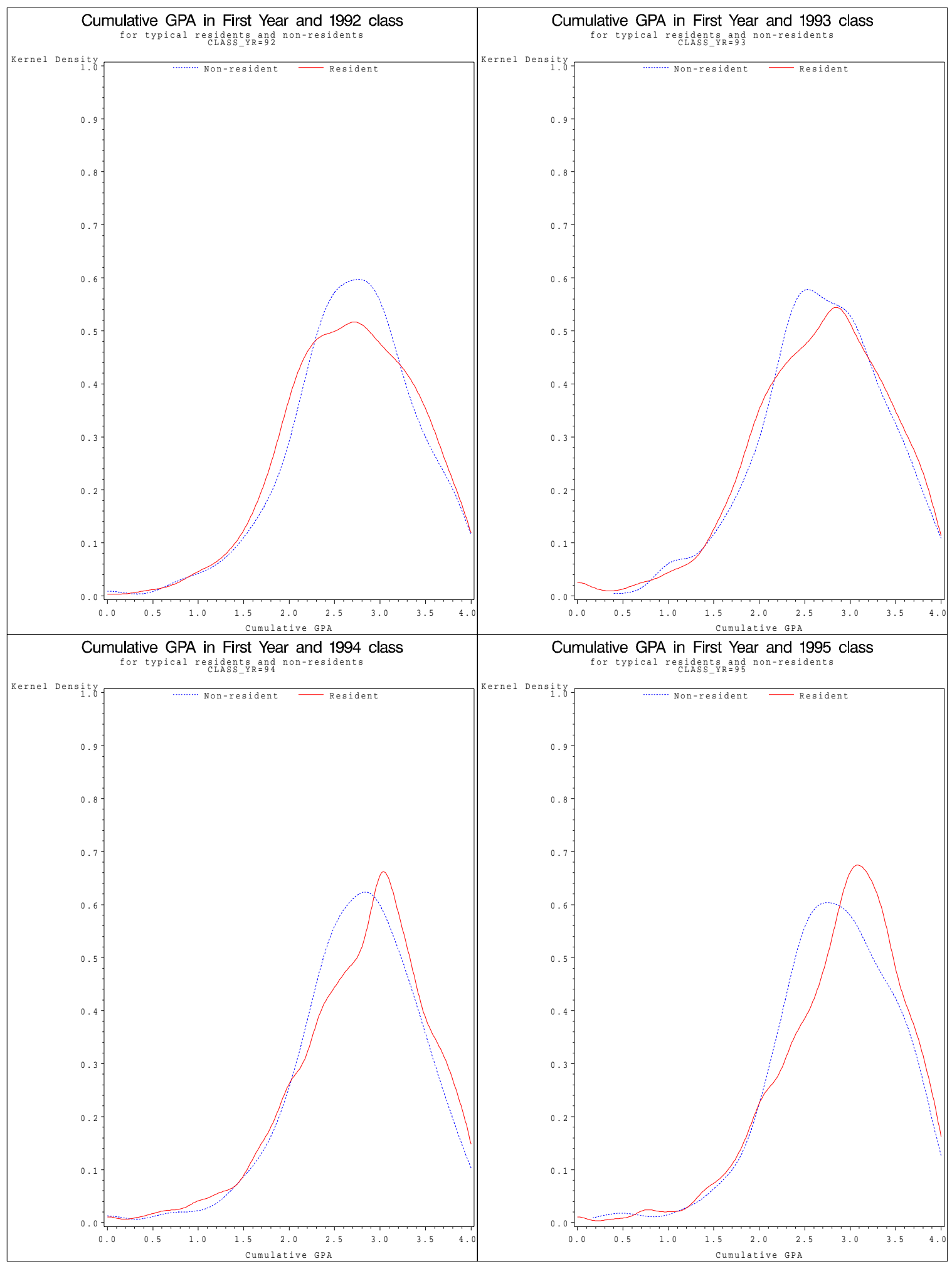


Figure 2 Percentage of Typical FTF Enrolling in Full Loads, Residents vs Non-residents

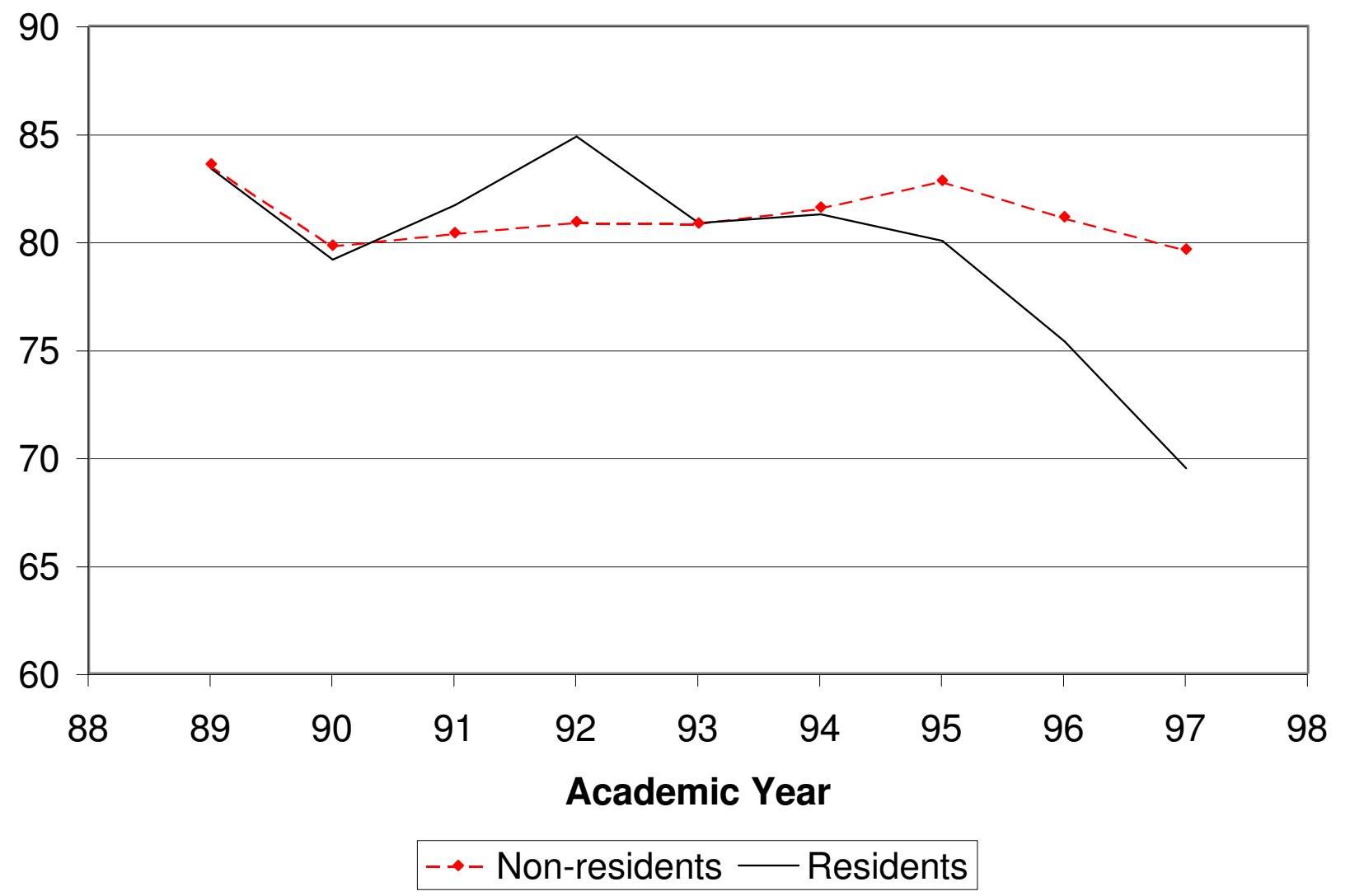


Figure 3 Percentage of Typical FTF Withdrawing from a Course, Residents vs Non-residents

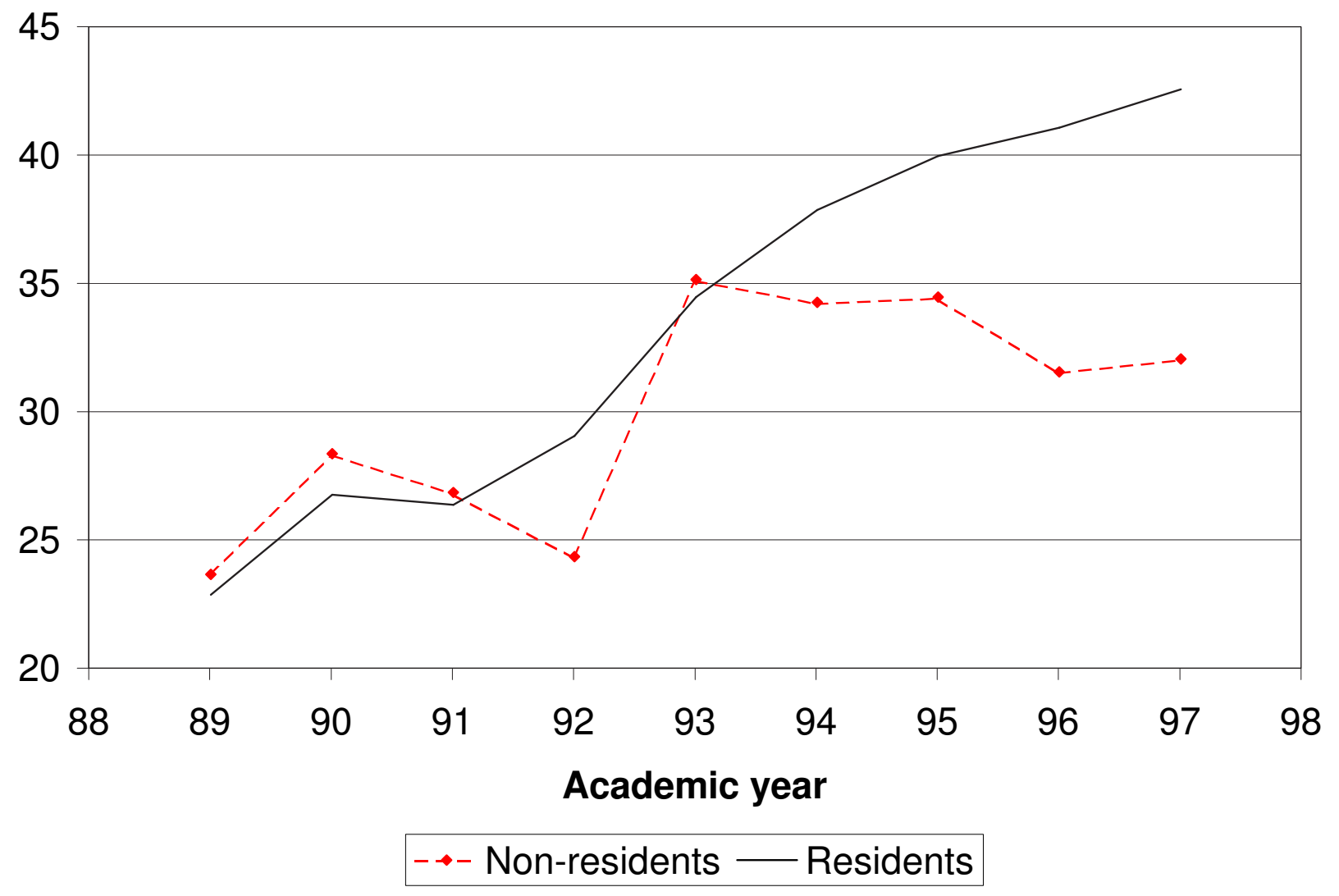


Figure 4 Percentage of Typical FTF Taking Full Loads, Residents vs Non-residents

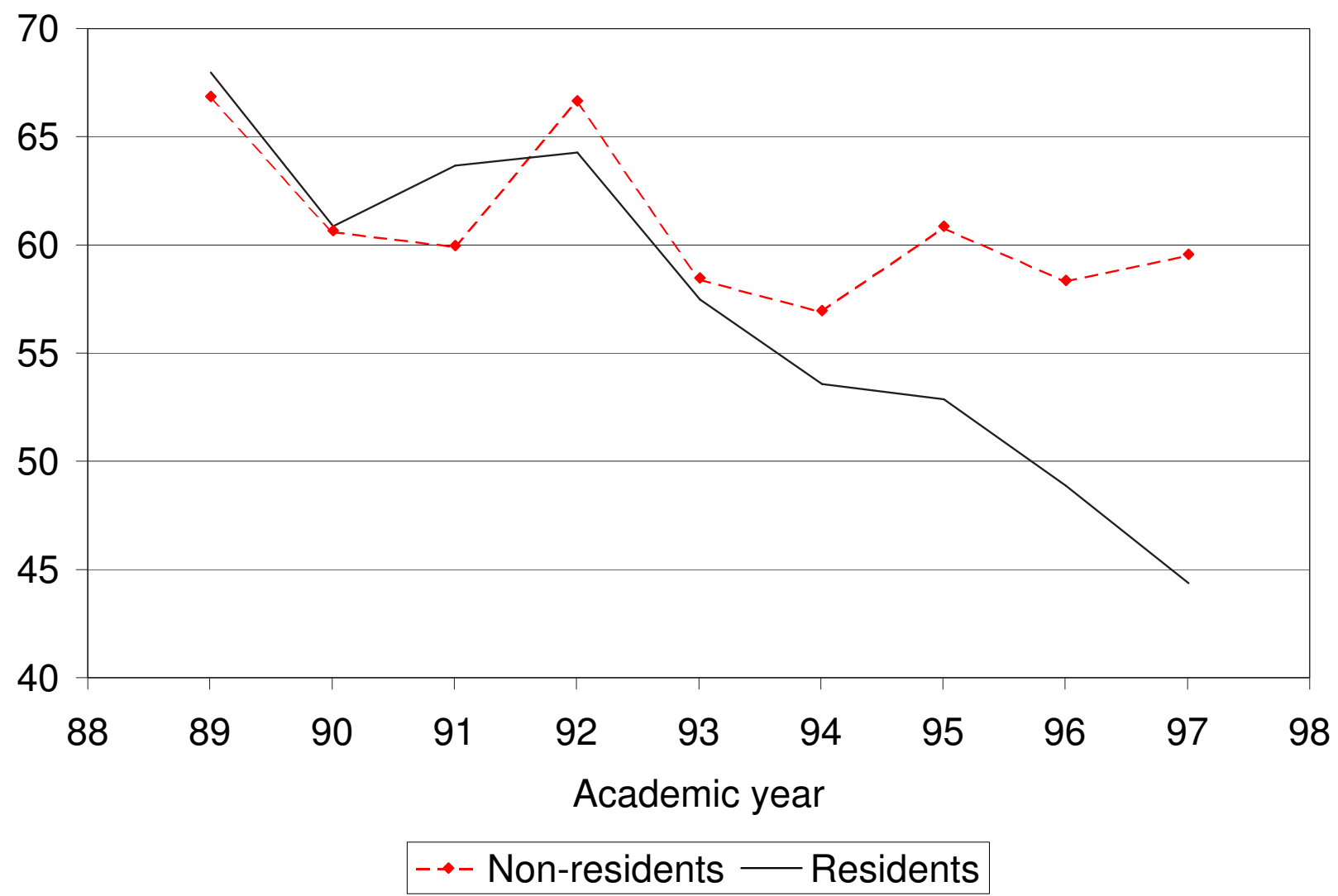


Table 1

Number and Percentage of Typical FTF Georgia Residents

Who Are Admitted as HOPE Scholars

\begin{tabular}{cccc}
\hline Class Year & TFTF & TFTF GA-Residents & TFTF HOPE Scholars \\
$N$ & & $N(\%)^{a}$ & $N(\%)^{b}$ \\
\hline \hline 1989 & 3,441 & $2,923(84.95)$ & $0(0.00)$ \\
1990 & 3,432 & $2,887(84.12)$ & $0(0.00)$ \\
1991 & 3,042 & $2,598(85.40)$ & $0(0.00)$ \\
1992 & 3,092 & $2,610(84.41)$ & $0(0.00)$ \\
1993 & 3,264 & $2,695(82.57)$ & $2,284(75.48)$ \\
1994 & 3,521 & $3,026(85.94)$ & $2,963(94.57)$ \\
1995 & 3,651 & $3,133(85.81)$ & $3,034(96.16)$ \\
1996 & 3,510 & $3,155(89.89)$ & $3,608(97.43)$ \\
1997 & 4,165 & $3,703(88.91)$ & $0(0.00)$ \\
\hline Post-HOPE (93-97) & 3,622 & $3,142(86.75)$ & $2,568(81.73)$ \\
\hline Mean & & & \\
\hline \hline
\end{tabular}

${ }^{a}$ Percent of typical FTF (TFTF) who are Georgia residents.

${ }^{b}$ Percent of TFTF Georgia residents who are admitted as HOPE Scholars. 
Table 2

Sample Means and Percentages for Typical First-Year Students

(standard deviations in parentheses)

\begin{tabular}{|c|c|c|c|c|}
\hline \multirow[b]{2}{*}{ Variable } & \multicolumn{2}{|c|}{ Pre-HOPE (1989-92) } & \multicolumn{2}{|c|}{ Post-HOPE (1993-97) } \\
\hline & Non-resident & Resident & Non-resident & Resident \\
\hline Full-Load Enrollment Rate ${ }^{a}(\%)$ & 81.2 & 82.2 & 81.2 & 77.0 \\
\hline Withdrawal Rate ${ }^{b}(\%)$ & 25.7 & 26.1 & 33.7 & 39.4 \\
\hline Full-Load Completion Rate ${ }^{c}(\%)$ & 63.5 & 64.2 & 58.8 & 50.9 \\
\hline Credit Hours Enrolled & $\begin{array}{l}43.65 \\
(7.13)\end{array}$ & $\begin{array}{l}44.22 \\
(6.22)\end{array}$ & $\begin{array}{l}44.10 \\
(6.95)\end{array}$ & $\begin{array}{l}44.25 \\
(5.86)\end{array}$ \\
\hline Credit Hours Withdrawn & $\begin{array}{c}1.61 \\
(3.29)\end{array}$ & $\begin{array}{c}1.57 \\
(3.18)\end{array}$ & $\begin{array}{c}2.10 \\
(3.66)\end{array}$ & $\begin{array}{c}2.53 \\
(3.92)\end{array}$ \\
\hline Credit Hours Taken & $\begin{array}{l}42.04 \\
(8.00)\end{array}$ & $\begin{array}{l}42.65 \\
(7.22)\end{array}$ & $\begin{array}{l}42.00 \\
(7.84)\end{array}$ & $\begin{array}{l}41.71 \\
(7.33)\end{array}$ \\
\hline High School GPA & $\begin{array}{c}3.05 \\
(0.45)\end{array}$ & $\begin{array}{c}3.23 \\
(0.49)\end{array}$ & $\begin{array}{c}3.26 \\
(0.43)\end{array}$ & $\begin{array}{c}3.47 \\
(0.41)\end{array}$ \\
\hline SAT Math Score & $\begin{array}{l}564.51 \\
(64.06)\end{array}$ & $\begin{array}{l}559.78 \\
(67.93)\end{array}$ & $\begin{array}{l}585.17 \\
(65.80)\end{array}$ & $\begin{array}{l}582.40 \\
(69.38)\end{array}$ \\
\hline SAT Verbal Score & $\begin{array}{l}574.01 \\
(73.63)\end{array}$ & $\begin{array}{l}565.92 \\
(77.26)\end{array}$ & $\begin{array}{l}592.70 \\
(73.21)\end{array}$ & $\begin{array}{l}589.22 \\
(71.74)\end{array}$ \\
\hline SAT Total Score & $\begin{array}{l}1138.52 \\
(113.63)\end{array}$ & $\begin{array}{l}1125.70 \\
(124.78)\end{array}$ & $\begin{array}{c}1177.88 \\
(117.89)\end{array}$ & $\begin{array}{c}1171.62 \\
(120.98)\end{array}$ \\
\hline AP Credit Hours Taken & $\begin{array}{c}3.27 \\
(6.10)\end{array}$ & $\begin{array}{c}2.77 \\
(6.01)\end{array}$ & $\begin{array}{c}5.24 \\
(8.38)\end{array}$ & $\begin{array}{c}4.55 \\
(8.15)\end{array}$ \\
\hline
\end{tabular}

${ }^{a}$ Percentage of typical first-year students enrolling in a full-credit load.

${ }^{b}$ Percentage of typical first-year students withdrawing from a class.

${ }^{c}$ Percentage of typical first-year students completing a full-credit load. 
Table 3

Estimated HOPE Effect on Admission Characteristics

Typical Students ${ }^{a}, 1989-97$

(Robust Standard Errors in Parentheses)

\begin{tabular}{lccccc}
\hline & \multicolumn{3}{c}{ SAT Scores $^{b}$} & HSGPA & AP Credits \\
\cline { 2 - 4 } Variables & Math & Verbal & Total & & \\
\hline \hline \multirow{2}{*}{$G A \cdot H$} & 0.718 & 4.479 & 5.197 & 0.017 & -0.244 \\
& $(2.044)$ & $(2.385)$ & $(3.673)$ & $(0.014)$ & $(0.234)$ \\
& & & & & Yes \\
Class Year Effects & Yes & Yes & Yes & Yes & Yes \\
Residency & Yes & Yes & Yes & Yes & Yes \\
Gender and Race & Yes & Yes & Yes & Yes & \\
\cline { 2 - 4 }$R^{2}$ & & & & & 0.037 \\
$N$ & 0.175 & 0.103 & 0.170 & 0.167 & 31,118 \\
\hline \hline
\end{tabular}

${ }^{a}$ Typical students refer to those who matriculate at UGA in the fall term of the same year as they graduate from high school.

${ }^{b}$ Since the College Board recentered SAT scores for tests taken on or after 1 April 1995, SAT verbal and math scores prior to 1995-class year are recentered according to the College Board's SAT I individual score conversion table. 
Table 4

Estimated HOPE Effect on

Full-Load Enrollment, Course Withdrawal and Full-Load Completion ${ }^{a}$

Typical First-Year Students ${ }^{b}, 1989-97$

(Robust Standard Errors in Parentheses)

\begin{tabular}{|c|c|c|c|c|c|c|}
\hline \multirow[b]{2}{*}{ Variables } & \multicolumn{2}{|c|}{ Enrolled } & \multicolumn{2}{|c|}{ Withdrawn } & \multicolumn{2}{|c|}{ Taken } \\
\hline & (1) & $(2)$ & (3) & (4) & (5) & $(6)$ \\
\hline$G A \cdot H$ & $\begin{array}{l}-0.045 \\
(0.013)\end{array}$ & $\begin{array}{l}-0.047 \\
(0.013)\end{array}$ & $\begin{array}{c}0.048 \\
(0.015)\end{array}$ & $\begin{array}{c}0.045 \\
(0.015)\end{array}$ & $\begin{array}{c}-0.076 \\
(0.016)\end{array}$ & $\begin{array}{c}-0.074 \\
(0.016)\end{array}$ \\
\hline$G A$ & $\begin{array}{c}0.012 \\
(0.009)\end{array}$ & $\begin{array}{l}-0.004 \\
(0.010)\end{array}$ & $\begin{array}{l}-0.001 \\
(0.011)\end{array}$ & $\begin{array}{c}0.029 \\
(0.011)\end{array}$ & $\begin{array}{c}0.011 \\
(0.012)\end{array}$ & $\begin{array}{c}-0.020 \\
(0.012)\end{array}$ \\
\hline FEMALE & $\begin{array}{c}0.022 \\
(0.005)\end{array}$ & $\begin{array}{c}0.012 \\
(0.005)\end{array}$ & $\begin{array}{l}-0.050 \\
(0.005)\end{array}$ & $\begin{array}{c}-0.030 \\
(0.006)\end{array}$ & $\begin{array}{c}0.052 \\
(0.006)\end{array}$ & $\begin{array}{c}0.032 \\
(0.006)\end{array}$ \\
\hline$A S I A N$ & $\begin{array}{c}0.045 \\
(0.013)\end{array}$ & $\begin{array}{c}0.037 \\
(0.013)\end{array}$ & $\begin{array}{c}0.000 \\
(0.016)\end{array}$ & $\begin{array}{c}0.029 \\
(0.016)\end{array}$ & $\begin{array}{c}0.043 \\
(0.017)\end{array}$ & $\begin{array}{c}0.016 \\
(0.016)\end{array}$ \\
\hline$B L A C K$ & $\begin{array}{l}-0.013 \\
(0.008)\end{array}$ & $\begin{array}{c}0.031 \\
(0.009)\end{array}$ & $\begin{array}{c}0.051 \\
(0.010)\end{array}$ & $\begin{array}{l}-0.002 \\
(0.010)\end{array}$ & $\begin{array}{l}-0.033 \\
(0.010)\end{array}$ & $\begin{array}{c}0.043 \\
(0.011)\end{array}$ \\
\hline$H I S P N$ & $\begin{array}{l}-0.016 \\
(0.024)\end{array}$ & $\begin{array}{l}-0.021 \\
(0.024)\end{array}$ & $\begin{array}{c}0.020 \\
(0.028)\end{array}$ & $\begin{array}{c}0.029 \\
(0.028)\end{array}$ & $\begin{array}{c}0.005 \\
(0.029)\end{array}$ & $\begin{array}{l}-0.006 \\
(0.028)\end{array}$ \\
\hline OTHER & $\begin{array}{l}-0.007 \\
(0.029)\end{array}$ & $\begin{array}{l}-0.011 \\
(0.028)\end{array}$ & $\begin{array}{c}0.021 \\
(0.032)\end{array}$ & $\begin{array}{c}0.015 \\
(0.031)\end{array}$ & $\begin{array}{l}-0.001 \\
(0.033)\end{array}$ & $\begin{array}{l}-0.003 \\
(0.032)\end{array}$ \\
\hline$H S G P A$ & & $\begin{array}{c}0.082 \\
(0.006)\end{array}$ & & $\begin{array}{l}-0.143 \\
(0.007)\end{array}$ & & $\begin{array}{c}0.166 \\
(0.007)\end{array}$ \\
\hline SATV & & $\begin{array}{c}0.019 \\
(0.004)\end{array}$ & & $\begin{array}{c}0.013 \\
(0.004)\end{array}$ & & $\begin{array}{c}0.007 \\
(0.005)\end{array}$ \\
\hline$S A T M$ & & $\begin{array}{c}0.005 \\
(0.004)\end{array}$ & & $\begin{array}{c}-0.015 \\
(0.005)\end{array}$ & & $\begin{array}{c}0.018 \\
(0.005)\end{array}$ \\
\hline$A P$ & & $\begin{array}{c}0.003 \\
(0.000)\end{array}$ & & $\begin{array}{c}-0.005 \\
(0.000)\end{array}$ & & $\begin{array}{c}0.006 \\
(0.000)\end{array}$ \\
\hline Class Year Effects & Yes & Yes & Yes & Yes & Yes & Yes \\
\hline$R^{2}$ & 0.012 & 0.031 & 0.024 & 0.053 & 0.024 & 0.068 \\
\hline$N$ & 31,117 & 30,705 & 31,117 & 30,705 & 31,117 & 30,705 \\
\hline
\end{tabular}

${ }^{a}$ (i) Probability that a student takes a full load in the first year; $y_{i t}=1$ if credits taken $\geq 45$.

(ii) Probability that a student enrolls in a full load in the first year; $y_{i t}=1$ if credits enrolled $\geq 45$.

(iii) Probability that a student withdraws from a course in the first year; $y_{i t}=1$ if credits withdrawn $\geq 0$.

Note: credit hours taken $=$ credit hours enrolled - credit hours withdrawn.

${ }^{b}$ Typical students refer to those who matriculate at UGA in the fall term of the same year as they graduate from high school. 
Table 5

Estimated HOPE Effect on

Credit Hours Enrolled, Withdrawn and Taken ${ }^{a}$

Typical First-Year Students ${ }^{b}$, 1989-97

(Robust Standard Errors in Parentheses)

\begin{tabular}{|c|c|c|c|c|c|c|}
\hline \multirow[b]{2}{*}{ Variables } & \multicolumn{2}{|c|}{ Enrolled } & \multicolumn{2}{|c|}{ Withdrawn } & \multicolumn{2}{|c|}{ Taken } \\
\hline & (1) & (2) & (3) & (4) & (5) & (6) \\
\hline$G A \cdot H$ & $\begin{array}{l}-0.426 \\
(0.227)\end{array}$ & $\begin{array}{l}-0.402 \\
(0.231)\end{array}$ & $\begin{array}{c}0.428 \\
(0.113)\end{array}$ & $\begin{array}{c}0.404 \\
(0.116)\end{array}$ & $\begin{array}{l}-0.854 \\
(0.257)\end{array}$ & $\begin{array}{c}-0.806 \\
(0.261)\end{array}$ \\
\hline$G A$ & $\begin{array}{c}0.519 \\
(0.170)\end{array}$ & $\begin{array}{c}0.438 \\
(0.175)\end{array}$ & $\begin{array}{l}-0.072 \\
(0.080)\end{array}$ & $\begin{array}{c}0.155 \\
(0.083)\end{array}$ & $\begin{array}{c}0.591 \\
(0.192)\end{array}$ & $\begin{array}{c}0.283 \\
(0.197)\end{array}$ \\
\hline$F E M A L E$ & $\begin{array}{l}-0.055 \\
(0.070)\end{array}$ & $\begin{array}{l}-0.084 \\
(0.075)\end{array}$ & $\begin{array}{l}-0.365 \\
(0.042)\end{array}$ & $\begin{array}{l}-0.201 \\
(0.044)\end{array}$ & $\begin{array}{c}0.310 \\
(0.085)\end{array}$ & $\begin{array}{c}0.117 \\
(0.090)\end{array}$ \\
\hline$A S I A N$ & $\begin{array}{c}0.707 \\
(0.210)\end{array}$ & $\begin{array}{c}0.475 \\
(0.207)\end{array}$ & $\begin{array}{c}-0.002 \\
(0.127)\end{array}$ & $\begin{array}{c}0.238 \\
(0.128)\end{array}$ & $\begin{array}{c}0.710 \\
(0.251)\end{array}$ & $\begin{array}{c}0.237 \\
(0.246)\end{array}$ \\
\hline$B L A C K$ & $\begin{array}{c}1.020 \\
(0.112)\end{array}$ & $\begin{array}{c}1.464 \\
(0.122)\end{array}$ & $\begin{array}{c}0.296 \\
(0.072)\end{array}$ & $\begin{array}{l}-0.084 \\
(0.078)\end{array}$ & $\begin{array}{c}0.724 \\
(0.135)\end{array}$ & $\begin{array}{c}1.548 \\
(0.148)\end{array}$ \\
\hline$H I S P N$ & $\begin{array}{l}-0.033 \\
(0.401)\end{array}$ & $\begin{array}{l}-0.283 \\
(0.402)\end{array}$ & $\begin{array}{c}0.041 \\
(0.207)\end{array}$ & $\begin{array}{c}0.088 \\
(0.206)\end{array}$ & $\begin{array}{l}-0.074 \\
(0.482)\end{array}$ & $\begin{array}{l}-0.371 \\
(0.474)\end{array}$ \\
\hline OTHER & $\begin{array}{l}-0.422 \\
(0.482)\end{array}$ & $\begin{array}{l}-0.520 \\
(0.482)\end{array}$ & $\begin{array}{c}0.364 \\
(0.275)\end{array}$ & $\begin{array}{c}0.332 \\
(0.272)\end{array}$ & $\begin{array}{c}-0.786 \\
(0.584)\end{array}$ & $\begin{array}{c}-0.852 \\
(0.576)\end{array}$ \\
\hline$H S G P A$ & & $\begin{array}{c}0.733 \\
(0.095)\end{array}$ & & $\begin{array}{c}-1.149 \\
(0.056)\end{array}$ & & $\begin{array}{c}1.882 \\
(0.113)\end{array}$ \\
\hline$S A T V$ & & $\begin{array}{l}-0.044 \\
(0.060)\end{array}$ & & $\begin{array}{c}0.125 \\
(0.035)\end{array}$ & & $\begin{array}{c}-0.168 \\
(0.072)\end{array}$ \\
\hline$S A T M$ & & $\begin{array}{c}0.191 \\
(0.066)\end{array}$ & & $\begin{array}{l}-0.106 \\
(0.039)\end{array}$ & & $\begin{array}{c}0.298 \\
(0.079)\end{array}$ \\
\hline$A P$ & & $\begin{array}{c}0.070 \\
(0.005)\end{array}$ & & $\begin{array}{l}-0.034 \\
(0.003)\end{array}$ & & $\begin{array}{c}0.104 \\
(0.006)\end{array}$ \\
\hline Class Year Effects & Yes & Yes & Yes & Yes & Yes & Yes \\
\hline$R^{2}$ & 0.004 & 0.018 & 0.020 & 0.049 & 0.006 & 0.038 \\
\hline$N$ & 31,117 & 30,705 & 31,117 & 30,705 & 31,117 & 30,705 \\
\hline
\end{tabular}

${ }^{a}$ Number of credit hours (i) taken, (ii) enrolled, or (iii) withdrawn by a typical student $i$ in the first year. Note that (i) $=($ ii $)-($ iii).

${ }^{b}$ Typical students refer to those who matriculate at UGA in the fall term of the same year as they graduate from high school. 
Table 6

Estimated HOPE Effects on

Full-Load Enrollment, Course Withdrawal and Full-Load Completion ${ }^{a}$

by Cumulative GPA Categories ${ }^{b}$

Typical First-Year Students, 1989-97

(Robust Standard Errors in Parentheses)

\begin{tabular}{ccccc}
\hline & GPA1 & GPA2 & GPA3 & GPA4 \\
Variables & $(<2.7)$ & $(2.7-3.3)$ & $(3.3-3.5)$ & $(>3.5)$ \\
\hline \hline
\end{tabular}

A. Full-Load Enrollment

$\begin{array}{lcccr}G A \cdot H & -0.087 & -0.051 & -0.004 & -0.005 \\ & (0.021) & (0.021) & (0.039) & (0.032) \\ R^{2} & 0.043 & 0.020 & 0.010 & 0.014\end{array}$

B. Course Withdrawal

$\begin{array}{lcccr}G A \cdot H & 0.074 & 0.031 & 0.037 & 0.015 \\ R^{2} & (0.024) & (0.026) & (0.046) & (0.035) \\ & 0.066 & 0.037 & 0.028 & 0.018\end{array}$

C. Full-Load Completion

$G A \cdot H$

$-0.103$

$-0.091$

$-0.069$

$-0.015$

$(0.024)$

(0.028)

(0.051)

(0.039)

$R^{2}$

0.076

0.047

0.036

0.026

Class Year Effects

Residency

Gender and Race

HS Characteristics

\section{Yes}

Yes

Yes

Yes

Yes

Yes

Yes

Yes

Yes

Yes

Yes

Yes

Yes

Yes

Yes

Yes

$N$

13,675

9,790

2,805

4,197

a (i) Probability that a student takes a full load in the first year; $y_{i t}=1$ if credits taken $\geq 45$.

(ii) Probability that a student enrolls in a full load in the first year; $y_{i t}=1$ if credits enrolled $\geq 45$.

(iii) Probability that a student withdraws from a course in the first year; $y_{i t}=1$ if credits withdrawn $\geq 0$.

Note: credit hours taken $=$ credit hours enrolled - credit hours withdrawn.

${ }^{b}$ Cumulative GPA is computed at the end of the spring term by averaging earned grade points since UGA matriculation. 
Table 7

Estimated HOPE Effects on

Credit Hours Enrolled, Withdrawn and Taken ${ }^{a}$

by Cumulative GPA Categories ${ }^{b}$

Typical First-Year Students, 1989-97

(Robust Standard Errors in Parentheses)

\begin{tabular}{lcccc}
\hline Variables & GPA1 & GPA2 & GPA3 & GPA4 \\
$(<2.7)$ & $(2.7-3.3)$ & $(3.3-3.5)$ & $(>3.5)$ \\
\hline \hline A. Credit Hours Enrolled & & & & \\
GA $\cdot H$ & -0.924 & -0.313 & -0.137 & 0.109 \\
& $(0.366)$ & $(0.317)$ & $(0.869)$ & $(0.587)$ \\
$R^{2}$ & 0.018 & 0.010 & 0.019 & 0.031 \\
B. Credit Hours Withdrawn & & & & \\
$G A \cdot H$ & 0.642 & 0.211 & 0.383 & 0.262 \\
& $(0.197)$ & $(0.174)$ & $(0.318)$ & $(0.244)$ \\
$R^{2}$ & 0.066 & 0.033 & 0.025 & 0.019 \\
C. Credit Hours Taken & & & & \\
$G A \cdot H$ & -1.566 & -0.524 & -0.521 & -0.153 \\
& $(0.405)$ & $(0.359)$ & $(0.903)$ & $(0.626)$ \\
$R^{2}$ & 0.044 & 0.022 & 0.027 & 0.042 \\
& & & & \\
Class Year Effects & Yes & Yes & Yes & Yes \\
Residency & Yes & Yes & Yes & Yes \\
Gender and Race & Yes & Yes & Yes & Yes \\
HS Characteristics & Yes & Yes & Yes & Yes \\
$N$ & 13,675 & 9,790 & 2,805 & 4,197 \\
\hline \hline
\end{tabular}

${ }^{a}$ Number of credit hours (i) taken, (ii) enrolled, or (iii) withdrawn by a typical student $i$ in the first year. Note that (i) $=($ ii $)-$ (iii).

${ }^{b}$ Cumulative GPA is computed at the end of the spring term by averaging earned grade points since UGA matriculation. 
Table 8

Temporal Pattern of Estimated HOPE Effect on

Full-Load Enrollment, Course Withdrawal and Full-Load Completion ${ }^{a}$

Typical First-Year Students ${ }^{b}, 1989-97$

(Robust Standard Errors in Parentheses)

\begin{tabular}{|c|c|c|c|}
\hline Variables & Enrolled & Withdrawn & Taken \\
\hline$G A \cdot H_{89}$ & $\begin{array}{c}0.001 \\
(0.026)\end{array}$ & $\begin{array}{c}-0.011 \\
(0.030)\end{array}$ & $\begin{array}{c}0.026 \\
(0.032)\end{array}$ \\
\hline$G A \cdot H_{90}$ & $\begin{array}{l}-0.005 \\
(0.027)\end{array}$ & $\begin{array}{l}-0.002 \\
(0.031)\end{array}$ & $\begin{array}{c}0.007 \\
(0.033)\end{array}$ \\
\hline$G A \cdot H_{91}$ & $\begin{array}{c}0.013 \\
(0.028)\end{array}$ & $\begin{array}{c}0.005 \\
(0.032)\end{array}$ & $\begin{array}{c}0.038 \\
(0.034)\end{array}$ \\
\hline$G A \cdot H_{92}$ & $\begin{array}{c}0.032 \\
(0.027)\end{array}$ & $\begin{array}{c}0.066 \\
(0.031)\end{array}$ & $\begin{array}{c}-0.034 \\
(0.033)\end{array}$ \\
\hline$G A \cdot H_{94}$ & $\begin{array}{l}-0.005 \\
(0.027)\end{array}$ & $\begin{array}{c}0.066 \\
(0.032)\end{array}$ & $\begin{array}{c}-0.047 \\
(0.033)\end{array}$ \\
\hline$G A \cdot H_{95}$ & $\begin{array}{l}-0.044 \\
(0.026)\end{array}$ & $\begin{array}{c}0.062 \\
(0.032)\end{array}$ & $\begin{array}{c}-0.087 \\
(0.033)\end{array}$ \\
\hline$G A \cdot H_{96}$ & $\begin{array}{l}-0.058 \\
(0.029)\end{array}$ & $\begin{array}{c}0.087 \\
(0.035)\end{array}$ & $\begin{array}{c}-0.081 \\
(0.037)\end{array}$ \\
\hline$G A \cdot H_{97}$ & $\begin{array}{l}-0.091 \\
(0.028)\end{array}$ & $\begin{array}{c}0.095 \\
(0.033)\end{array}$ & $\begin{array}{c}-0.120 \\
(0.034)\end{array}$ \\
\hline Class Year Effects & Yes & Yes & Yes \\
\hline Residency & Yes & Yes & Yes \\
\hline Gender and Race & Yes & Yes & Yes \\
\hline HS Characteristics & Yes & Yes & Yes \\
\hline$R^{2}$ & 0.031 & 0.053 & 0.068 \\
\hline
\end{tabular}

${ }^{a}$ (i) Probability that a student takes a full load in the first year; $y_{i t}=1$ if credits taken $\geq 45$.

(ii) Probability that a student enrolls in a full load in the first year; $y_{i t}=1$ if credits enrolled $\geq 45$.

(iii) Probability that a student withdraws from a course in the first year; $y_{i t}=1$ if credits withdrawn $\geq 0$.

Note: credit hours taken $=$ credit hours enrolled - credit hours withdrawn

${ }^{b}$ Typical first-year students refer to those who matriculate at UGA in the fall term of the same year as they graduate from high school, and are in their first year of UGA attendance. 
Table 9

Temporal Pattern of Estimated HOPE Effect on

Credit Hours Enrolled, Withdrawn and Taken ${ }^{a}$

Typical First-Year Students ${ }^{b}, 1989-97$

(Robust Standard Errors in Parentheses)

\begin{tabular}{|c|c|c|c|}
\hline Variables & Enrolled & Withdrawn & Taken \\
\hline$G A \cdot H_{89}$ & $\begin{array}{c}0.397 \\
(0.466)\end{array}$ & $\begin{array}{c}0.099 \\
(0.237)\end{array}$ & $\begin{array}{c}0.297 \\
(0.535)\end{array}$ \\
\hline$G A \cdot H_{90}$ & $\begin{array}{c}0.353 \\
(0.484)\end{array}$ & $\begin{array}{c}0.032 \\
(0.246)\end{array}$ & $\begin{array}{c}0.321 \\
(0.551)\end{array}$ \\
\hline$G A \cdot H_{91}$ & $\begin{array}{c}0.345 \\
(0.507)\end{array}$ & $\begin{array}{c}0.106 \\
(0.248)\end{array}$ & $\begin{array}{c}0.239 \\
(0.570)\end{array}$ \\
\hline$G A \cdot H_{92}$ & $\begin{array}{l}-0.049 \\
(0.472)\end{array}$ & $\begin{array}{c}0.451 \\
(0.245)\end{array}$ & $\begin{array}{c}-0.500 \\
(0.539)\end{array}$ \\
\hline$G A \cdot H_{94}$ & $\begin{array}{c}0.311 \\
(0.501)\end{array}$ & $\begin{array}{c}0.548 \\
(0.269)\end{array}$ & $\begin{array}{c}-0.236 \\
(0.569)\end{array}$ \\
\hline$G A \cdot H_{95}$ & $\begin{array}{l}-0.802 \\
(0.428)\end{array}$ & $\begin{array}{c}0.646 \\
(0.245)\end{array}$ & $\begin{array}{c}-1.448 \\
(0.498)\end{array}$ \\
\hline$G A \cdot H_{96}$ & $\begin{array}{c}0.134 \\
(0.538)\end{array}$ & $\begin{array}{c}0.759 \\
(0.280)\end{array}$ & $\begin{array}{l}-0.625 \\
(0.604)\end{array}$ \\
\hline$G A \cdot H_{97}$ & $\begin{array}{l}-0.255 \\
(0.476)\end{array}$ & $\begin{array}{c}1.022 \\
(0.248)\end{array}$ & $\begin{array}{c}-1.277 \\
(0.532)\end{array}$ \\
\hline Class Year Effects & Yes & Yes & Yes \\
\hline Residency & Yes & Yes & Yes \\
\hline Gender and Race & Yes & Yes & Yes \\
\hline HS Characteristics & Yes & Yes & Yes \\
\hline$R^{2}$ & 0.018 & 0.050 & 0.038 \\
\hline
\end{tabular}

${ }^{a}$ Number of credit hours (i) taken, (ii) enrolled, or (iii) withdrawn by a typical student $i$ in the first year. Note that (i) $=($ ii $)-($ iii $)$.

${ }^{b}$ Typical first-year students refer to those who matriculate at UGA in the fall term of the same year as they graduate from high school, and are in their first year of UGA attendance. 
Table 10

Estimated HOPE Effect on Intertemporal Substitution

Typical Students, 1989-97

(Robust Standard Errors in Parentheses)

\begin{tabular}{|c|c|c|c|c|}
\hline Variables & 1st-Year & 2nd-Year & 3rd-Year & 4th-Year \\
\hline \multicolumn{5}{|c|}{ A. Probability of Taking Full-Load ${ }^{a}$} \\
\hline$G A \cdot H$ & $\begin{array}{c}-0.074 \\
(0.016)\end{array}$ & $\begin{array}{c}0.004 \\
(0.019)\end{array}$ & $\begin{array}{c}0.006 \\
(0.020)\end{array}$ & $\begin{array}{r}-0.011 \\
(0.024)\end{array}$ \\
\hline$R^{2}$ & 0.068 & 0.041 & 0.036 & 0.030 \\
\hline \multicolumn{5}{|c|}{ B. Annual Credit Hours Taken ${ }^{b}$} \\
\hline$G A \cdot H$ & $\begin{array}{c}-0.806 \\
(0.261)\end{array}$ & $\begin{array}{c}0.171 \\
(0.380)\end{array}$ & $\begin{array}{c}0.800 \\
(0.459)\end{array}$ & $\begin{array}{c}0.561 \\
(0.576)\end{array}$ \\
\hline$R^{2}$ & 0.038 & 0.053 & 0.044 & 0.033 \\
\hline Class Year Effects & Yes & Yes & Yes & Yes \\
\hline Residency & Yes & Yes & Yes & Yes \\
\hline Gender and Race & Yes & Yes & Yes & Yes \\
\hline HS Characteristics & Yes & Yes & Yes & Yes \\
\hline$N$ & 31,705 & 23,645 & 18,771 & 14,595 \\
\hline
\end{tabular}

${ }^{a} y_{i t}=1$ if credits taken in the $t$-th school year $\geq 45$.

${ }^{b}$ Credit hours taken $=$ credit hours enrolled - credit hours withdrawn. 
Table 11

Estimated HOPE Effect on Intertemporal Substitution

Typical Students, 1990 and 95 Classes

(Robust Standard Errors in Parentheses)

\begin{tabular}{lccc}
\hline Variables & 1st-Year & 2nd-Year & 3rd-Year \\
\hline \hline A. Probability of Taking Full-Load & & & \\
$G A \cdot H$ & & & \\
& & & \\
& & & \\
$R^{2}$ & $(0.033)$ & $(0.036)$ & $(0.037)$ \\
& 0.049 & 0.036 & 0.033 \\
B. Annual Credit Hours Taken ${ }^{b}$ & & & \\
$G A \cdot H$ & -1.674 & 0.913 & 0.325 \\
& $(0.501)$ & $(0.720)$ & $(0.858)$ \\
$R^{2}$ & 0.026 & 0.053 & 0.046 \\
& & & \\
Class Year Effect & & & \\
Residency & Yes & Yes & Yes \\
Gender and Race & Yes & Yes & Yes \\
HS Characteristics & Yes & Yes & Yes \\
$N$ & Yes & Yes & Yes \\
& 6,979 & 6,227 & 5,706 \\
\hline \hline
\end{tabular}

${ }^{a} y_{i t}=1$ if credits taken in the $t$-th school year $\geq 45$.

${ }^{b}$ Credit hours taken $=$ credit hours enrolled - credit hours withdrawn. 
Table 12

Estimated HOPE Effect on Summer Course Taking

by Year in School

Typical Students, 1989-96 Classes

(Robust Standard Errors in Parentheses)

\begin{tabular}{lccc}
\hline Variables & 2nd-Year ${ }^{a}$ & 3rd-Year & 4th-Year \\
\hline \hline A. Probability of Taking Summer Credits & & \\
GA $H$ & 0.035 & 0.021 & 0.005 \\
& $(0.016)$ & $(0.021)$ & $(0.025)$ \\
$R^{2}$ & 0.028 & 0.018 & 0.022 \\
B. Credit Hours Taken in Summer & & \\
GA H $H$ & 0.470 & 0.454 & 0.261 \\
& $(0.151)$ & $(0.211)$ & $(0.273)$ \\
$R^{2}$ & & & \\
& 0.023 & 0.016 & 0.023 \\
Class Year Effects & & & \\
Residency & & & \\
Gender and Race & Yes & Yes & Yes \\
HS Characteristics & Yes & Yes & Yes \\
$N$ & Yes & Yes & Yes \\
& Yes & Yes & Yes \\
\hline \hline
\end{tabular}

${ }^{a}$ The summer quarter in the second year is the summer immediately following the first academic year, which is the first summer at UGA for typical students, since the academic year runs from the summer to the next spring term.

${ }^{b} y_{i t}=1$ if credits taken in the summer of the $t$-th school year $>0$.

${ }^{c}$ Summer credit hours taken $=$ summer credit hours enrolled - summer credit hours withdrawn. 


\section{IZA Discussion Papers}

\begin{tabular}{|c|c|c|c|c|}
\hline No. & Author(s) & Title & Area & Date \\
\hline 806 & G. J. van den Berg & $\begin{array}{l}\text { Multiple Equilibria and Minimum Wages in Labor } \\
\text { Markets with Informational Frictions and } \\
\text { Heterogeneous Production Technologies }\end{array}$ & 6 & 06/03 \\
\hline 807 & $\begin{array}{l}\text { P. Frijters } \\
\text { M. A. Shields } \\
\text { N. Theodoropoulos } \\
\text { S. Wheatley Price }\end{array}$ & $\begin{array}{l}\text { Testing for Employee Discrimination Using } \\
\text { Matched Employer-Employee Data: } \\
\text { Theory and Evidence }\end{array}$ & 5 & 06/03 \\
\hline 808 & $\begin{array}{l}\text { F. Docquier } \\
\text { H. Rapoport }\end{array}$ & $\begin{array}{l}\text { Remittances and Inequality: A Dynamic } \\
\text { Migration Model }\end{array}$ & 1 & 06/03 \\
\hline 809 & $\begin{array}{l}\text { S. Commander } \\
\text { M. Kangasniemi } \\
\text { L. A. Winters }\end{array}$ & The Brain Drain: Curse or Boon? & 1 & $06 / 03$ \\
\hline 810 & $\begin{array}{l}\text { J. H. Abbring } \\
\text { G. J. van den Berg }\end{array}$ & $\begin{array}{l}\text { A Simple Procedure for the Evaluation of } \\
\text { Treatment Effects on Duration Variables }\end{array}$ & 6 & $06 / 03$ \\
\hline 811 & $\begin{array}{l}\text { M. Corak } \\
\text { W.-H. Chen }\end{array}$ & $\begin{array}{l}\text { Firms, Industries, and Unemployment Insurance: } \\
\text { An Analysis Using Employer-Employee Data }\end{array}$ & 1 & $06 / 03$ \\
\hline 812 & $\begin{array}{l}\text { J. T. Addison } \\
\text { T. Schank } \\
\text { C. Schnabel } \\
\text { J. Wagner }\end{array}$ & $\begin{array}{l}\text { German Works Councils in the Production } \\
\text { Process }\end{array}$ & 3 & $06 / 03$ \\
\hline 813 & E. P. Lazear & $\begin{array}{l}\text { Firm-Specific Human Capital: A Skill-Weights } \\
\text { Approach }\end{array}$ & 5 & $06 / 03$ \\
\hline 814 & $\begin{array}{l}\text { G. Ridder } \\
\text { G. J. van den Berg }\end{array}$ & $\begin{array}{l}\text { Measuring Labor Market Frictions: A Cross- } \\
\text { Country Comparison }\end{array}$ & 6 & $07 / 03$ \\
\hline 815 & $\begin{array}{l}\text { A. Aakvik } \\
\text { K. G. Salvanes } \\
\text { K. Vaage }\end{array}$ & $\begin{array}{l}\text { Measuring Heterogeneity in the Returns to } \\
\text { Education in Norway Using Educational Reforms }\end{array}$ & 6 & $07 / 03$ \\
\hline 816 & $\begin{array}{l}\text { T. T. Herbertsson } \\
\text { J. M. Orszag }\end{array}$ & $\begin{array}{l}\text { The Early Retirement Burden: Assessing the } \\
\text { Costs of the Continued Prevalence of Early } \\
\text { Retirement in OECD Countries }\end{array}$ & 3 & $07 / 03$ \\
\hline 817 & $\begin{array}{l}\text { T. M. Andersen } \\
\text { T. T. Herbertsson }\end{array}$ & Measuring Globalization & 2 & $07 / 03$ \\
\hline 818 & J. Pencavel & The Surprising Retreat of Union Britain & 3 & $07 / 03$ \\
\hline 819 & $\begin{array}{l}\text { M. Beine } \\
\text { F. Docquier } \\
\text { H. Rapoport }\end{array}$ & $\begin{array}{l}\text { Brain Drain and LDCs' Growth: Winners and } \\
\text { Losers }\end{array}$ & 1 & $07 / 03$ \\
\hline 820 & $\begin{array}{l}\text { C. M. Cornwell } \\
\text { K. H. Lee } \\
\text { D. B. Mustard }\end{array}$ & $\begin{array}{l}\text { The Effects of Merit-Based Financial Aid on } \\
\text { Course Enrollment, Withdrawal and Completion } \\
\text { in College }\end{array}$ & 6 & $07 / 03$ \\
\hline
\end{tabular}

An updated list of IZA Discussion Papers is available on the center's homepage www.iza.org. 